\title{
Article \\ Intangible Heritage and Territorial Identity in the Multifunctional Agrarian Systems of Vineyards in Castilla-La Mancha (Spain)
}

\author{
Ángel Raúl Ruiz Pulpón *(i) and María del Carmen Cañizares Ruiz
}

Citation: Ruiz Pulpón, Á.R.; Cañizares Ruiz, M.d.C. Intangible Heritage and Territorial Identity in the Multifunctional Agrarian Systems of Vineyards in Castilla-La Mancha (Spain). Land 2022, 11, 281 https://doi.org/10.3390/ land11020281

Academic Editors: Rafael Mata Olmo Nieves López-Estébanez, Rocío Silva Pérez, Jorge Hermosilla-Pla and Carolina Yacamán Ochoa

Received: 25 January 2022 Accepted: 11 February 2022 Published: 13 February 2022

Publisher's Note: MDPI stays neutral with regard to jurisdictional claims in published maps and institutional affiliations.

Copyright: (C) 2022 by the authors. Licensee MDPI, Basel, Switzerland. This article is an open access article distributed under the terms and conditions of the Creative Commons Attribution (CC BY) license (https:// creativecommons.org/licenses/by/ $4.0 /$ )

\author{
Department of Geography and Land Use Planning, University of Castilla-La Mancha, 13071 Ciudad Real, Spain; \\ mcarmen.canizares@uclm.es \\ * Correspondence: angelraul.ruiz@uclm.es
}

\begin{abstract}
Vine cultivation has a strong territorial character derived from the environmental, social, cultural and economic interactions with the space in which the vines are grown. In Spain, this activity is clearly representative of Mediterranean agrarian landscapes, where vineyards have a dynamic and multifunctional character, as a consequence of the social and economic processes that they have always incorporated. This character is also complex as it has natural and anthropic components. The links between vineyards and territories drive the configuration of identity-based feelings in local communities, which identify with the work, rituals and symbols that are present in the production and manufacturing processes. Therefore, territorial identity is a strategic key for the necessary revalorisation of endogenous resources, and it is a factor of territorial development, as well as an element that is needed to reaffirm the multifunctional character of the winemaking system. The aim of this paper is to study these kinds of identity-based elements in the vineyards of Castilla-La Mancha, the main wine production region in Spain, emphasising the elements that are related to intangible heritage, and specifically, their roles in festivals and folklore, which reinforce the territorial and multifunctional character of agrarian land use. In other words, not only do these factors promote the education and awareness of local cultures about the values of their territory from a heritage perspective, but they also have potential as tourist attractions, which can promote economic diversification of agricultural activities in the recent debates between productivism and post-productivism.
\end{abstract}

Keywords: vineyard; intangible heritage; territorial identity; multifunctional agrarian systems

\section{Introduction}

There is a great historical tradition of viticulture in the European countries of the Mediterranean basin [1]. In inland areas, the spread of vineyards is conditioned by factors such as summer aridity, cold winters and the presence of plains, factors which also affect other Mediterranean crops such as cereals and olives. The influence of these geographical factors can be more clearly recognised in the characteristics and qualities of the final product from grapevines than in any of the other crops. These characteristics include aspects such as soil type, hours of sunlight, the nature of air masses and humidity, which are interrelated with human factors such as know-how, tradition, agrarian land use systems, the ways in which production is organised and the perfection of agronomic techniques. All of these factors are present in the final product. These different elements interact in a specific area, acting as a spatial foundation, in which winemaking practices have been carried out for centuries, and that currently defines a landscape that expresses both tradition and modernity.

There are wine-producing areas in Southern Europe that have become structurally important in terms of the territories themselves and production. The Autonomous Region of Castilla-La Mancha, in inland Spain, is a good example of this, as $47.1 \%$ of the national surface area covered by vineyards is found here, and the region is responsible for $58 \%$ of 
total grape production and $53 \%$ of the total volume of exports [2]. These indicators show the importance of the winemaking sector in social and economic terms. It is a sector that is well structured and equipped to organise the production, manufacture and commercialisation of must, wines and other products derived from grapes. Moreover, this region has a solid network of agrarian cooperatives that are a key factor in territorial coordination, providing the foundations for a model of family-based agriculture with a system of land use based on direct ownership which coexists with other private organisational models that are concerned with the excellence and added value of their products. These socioeconomic features are culturally and territorially important as they are based on a historical landscape whose material testimonies still exist. It is undoubtedly an attractive type of landscape that conveys the harmony and beauty which has been captured by different writers and painters. All these factors are drivers of territorial identity in local communities, in which vineyards are the main way of life and making a living. These landscapes are associated with a rich tangible heritage, which can be mainly found in examples of agricultural buildings and structures (wineries), and also in intangible heritage (traditions, folklore, festivals), which is still deeply rooted in the communities. Taking these aspects into account, the research question would be based on the possibility that this intangible heritage could serve to reinforce the territorial identity of the people who live in the vineyard landscapes of Castilla-La Mancha. Therefore, the objective of this article is to identify these identity-based elements that are related to intangible heritage, specifically those found in festivals and folklore, as they reinforce the territorial and multifunctional character of land use. The revalorisation of these resources by local communities and institutions favours economic diversification, and once their tourism potential has been considered, the multifunctional character of these resources can also be revalorised. We also consider that, in the current socioeconomic context, which is clearly capitalist and globalised, the social and environmental benefits of agriculture are seen as something to be exploited. Thus, landscape, heritage and territory are perceived as new commodities that can be bought and sold [3]. Through the implementation of local initiatives that we will discuss later, we will try to show proposals that do not have strictly commercial objectives, but rather appear as reflections of the territorial identity of the people who inhabit these landscapes.

\subsection{The Vineyard as a Territorial and Multifunctional System}

The environmental, social, economic and cultural implications of vineyards form a territorial system in which there are different dynamics at play. Theses dynamics are associated with an increasingly globalised world that is dependent on market forces (Figure 1). On the one hand, a productivity-focused approach is predominant, based on the fact that the sector needs to adapt to the behaviour of the global markets. These efforts to adapt are driven by productive modernisation using new agricultural materials and supported by the mechanisation of agrarian activities that bring about improvements in performance and the general optimisation of all the means of production. However, these dynamics, which are as dominant in the agrarian environment as they are in current capitalism, are being countered by a post-productive, or non-productive, vision. This addresses a new framework of relationships between agrarian and environmental policies for the rural environment-policies that are mainly based on backing agrarian extensification, recognising the diversification of the activities of farms and agricultural holdings, the revalorisation of rural spaces, the breakup of regulatory frameworks, the heightened awareness of the environmental effects of intensive agrarian activities and the increase in the number of consumers that demand healthy, high quality products [4-7]. Doubts have been expressed about whether post-productivism actually exists [8], and there is disagreement about the suitability of the prefix post. Nevertheless, the concept has been presented as a temporary succession of productivism itself, with both coexisting [9]. This focus is clearly a logical response to the concerns of our current post-industrial society, and it shows an increasing interest in environmental and heritage conservation [10]. When applied to wine culture, 
post-productivism reflects, among other issues, the commitment to quality and the revalorisation of the heritage associated with this activity. Quality and heritage condition the creation of local identities and these can be drivers for integrated territorial development. We will go on to describe each of these drivers.

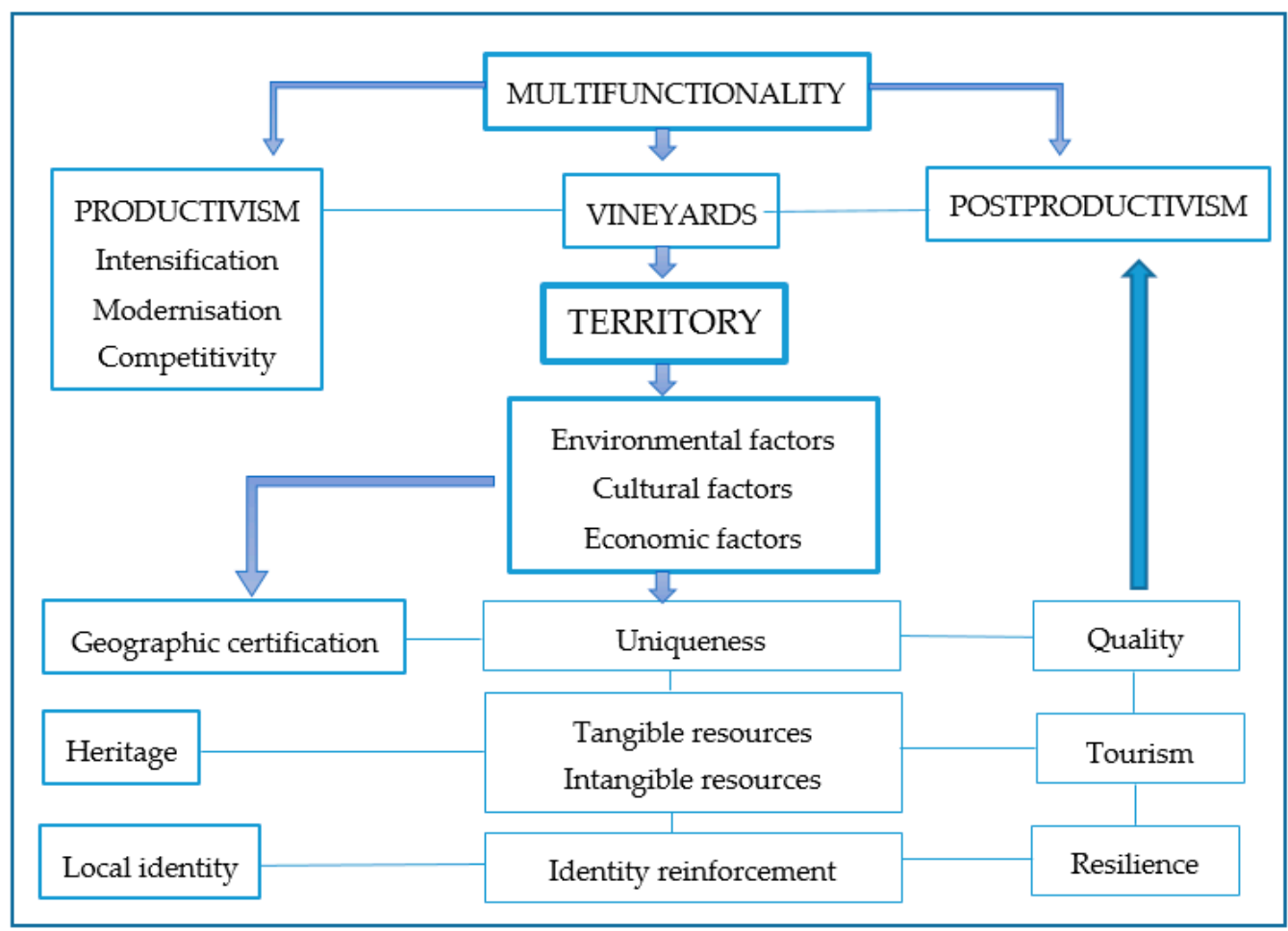

Figure 1. Vineyards as multifunctional and territorial systems. Created by the authors.

Wine is one of the few products where the specificity of quality can be most accurately verified with regard to other standardised products [11,12]. The perception of quality is a socially and psychologically constructed phenomenon in which the consumer subjectively confers specific qualities to a product, which they consider important. With wine, these qualities reflect the distinctive features of the production process, the certification of this process by a regulatory body and the appeal of its appearance or flavour [13,14]. The food certification processes recognise specific natural or cultural determinants that enable a unique product to be obtained which is an alternative to the standardised production of the global markets. Certification creates a direct connection between the product and the territory from which it came and in which it was manufactured. This helps to socially and economically revitalise wine producing areas, while reinforcing the spatial structures and networks that play an important role in territorial cohesion processes through the interaction between the agri-food industry and its social and institutional setting [15].

Grapes have been grown in the Castilla-La Mancha region since the time of the Phoenicians, the Greeks and the Romans [16] (p. 77). The region currently holds an Indicación Geográfica Protegida (Protected Geographical Indication) that covers the whole region, nine Denominaciones de Origen (Denominations of Origin) (Mancha, Valdepeñas, Almansa, Uclés, Méntrida, Manchuela, Mondéjar, Ribera del Júcar and Jumilla), and twelve Vinos de Pago con Denominación de Origen Propia (Estate Wines with their own Denomination of Origin) (Pagos Calzadilla, Campo de la Guardia, Casa del Blanco, Dehesa del Carrizal (Figure 2), Dominio del Valdepusa, Finca Élez, Guijoso, Pago Florentino, El Vicario, Pago de la Jaraba, los Cerrillos y Vallegarcía). With all these classifications, the geographical idiosyncrasy of each production area is expressed through the quality of the product. 


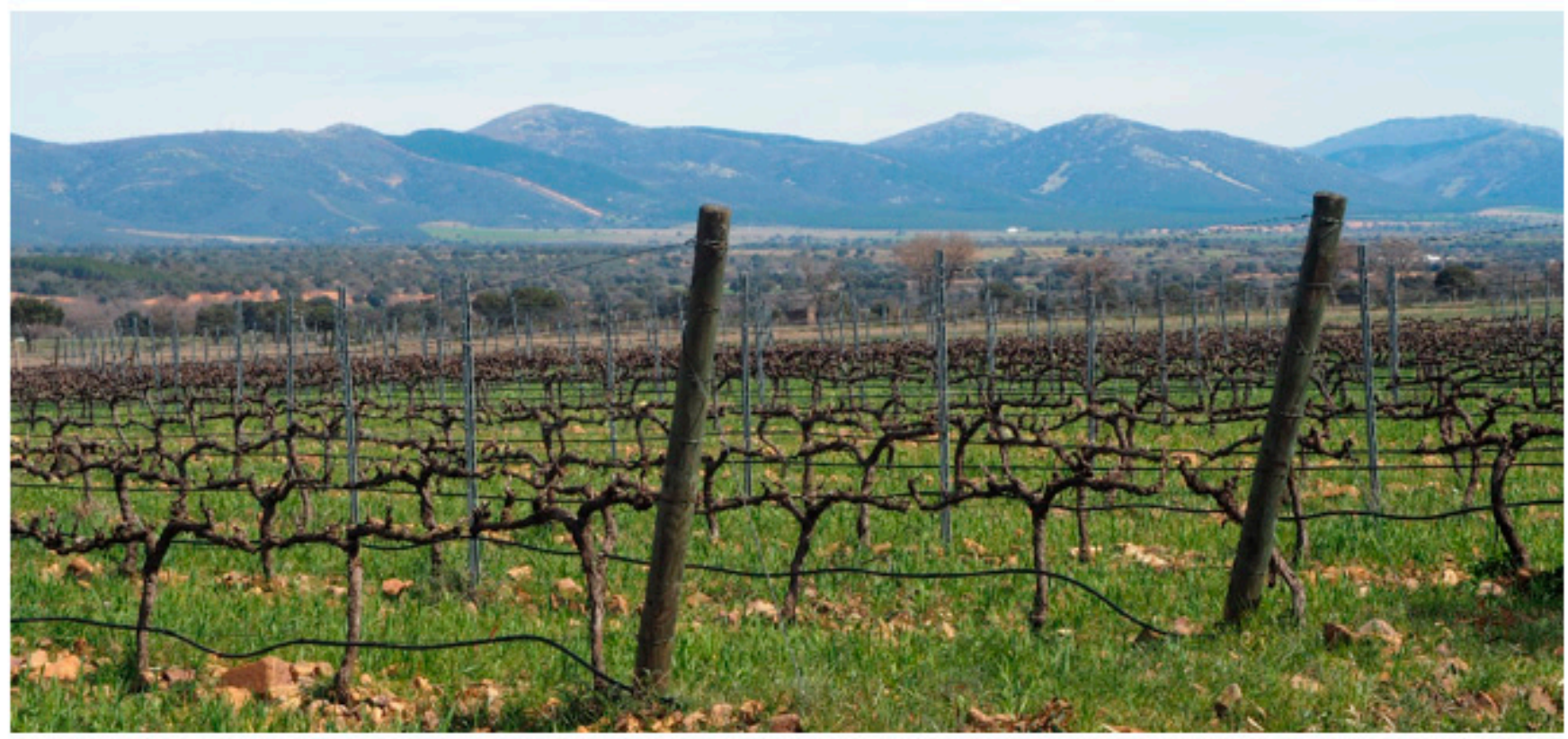

Figure 2. Vineyards in Pago Dehesa del Carrizal. Source: The authors.

The relationship between certification and quality is complemented by the connections established with heritage values and the reinforcement of territorial identity carried out by local communities. Tangible and intangible heritage resources are another potential factor for economic diversification for the sector since they can be developed into tourist attractions. These heritage resources are the legacy, or footprint, left by human activity, reinforcing both identity and resilience in many municipalities. The valorisation of these resources means that they become key territorial assets in territorial development processes [17] (p. 77). These processes enable better identification and awareness of these types of resources. The potential of these resources is of major importance as they can help a territory to prepare, resist and adapt to the circumstances of external changes that are typical of globalisation [18-20].

\subsection{Vineyards and the Territorial System: Cultural Landscape and Territorial Identity}

Vineyard landscapes are an excellent example of what the French geographer P. Pimchemel [21] (p. 12, et seq.) called Geosofía, a type of geographical wisdom that describes the cultural character of the landscape that is a consequence of different geographical influences (or spatial influences). He stated that these influences could help us read the results of some secular adjustments that present useful information about how natural influences and those created by humans interact and have interacted. Vineyard landscapes are obviously cultural landscapes, and UNESCO has recognised this by including some of them on the World Heritage List, confirming their "exceptional universal value". As assets that combine nature and society, vineyards illustrate the evolution of human society and settlements. This has been influenced by the physical limitations and/or opportunities that their natural surroundings and successive social, economic and cultural forces, both internal and external, have offered [22]. The Italian landscapes on the Amalfi coast have received recognition, as have the landscapes of the Cinque Terre, which are characterised by their terraced vineyards, among others.

In Spain, the Plan Nacional de Paisaje Cultural (2012) (the National Plan for Cultural Landscapes), which incorporates landscapes into heritage policies, provides a definition that is similar to the UNESCO definition. This plan takes a novel approach as it includes all landscapes, even the ordinary ones, instead of only considering those of exceptional value. Moreover, the plan emphasises the fact that landscapes are "the expression of a territory that is perceived and valued for its cultural qualities, the product of a process and the basis 
of the identity of a community" [23], which is similar to the ideas expressed in the European Landscape Convention (ELC) (2000), which indicated that the landscape "contributes to human wellbeing and to the consolidation of European identity" [24]. This identity is safeguarded as one of the most valuable cultural elements and, with the creation of the ELC, was treated with special attention in order to avoid social conflicts, such as nationalism. The local scale was considered to be the most suitable scale for the acknowledgement of the values of a territory [25] (pp. 195, et seq.). From a heritage perspective, each territory, with regard to the society that inhabits and integrates its landscapes, is also shown as a "reference of its identity and culture" [26], as the natural characteristics and the prevalence of the cultural evidence of the past offer "values of singularity and diversity". These values are extremely important in a global world that tends towards standardisation, and they must be preserved so that they can be passed on to future generations in the best possible way, in other words, by using criteria that focuses on sustainability.

Cultural interest in these types of landscapes is a consequence of the intrinsic cultural value that they possess, rather than only the beauty of the "final result". The vineyard landscapes are a good example of Agrarian, Livestock and Forest Landscapes (The work 100 Paisajes Culturales de España (2015) differentiates four groups of cultural landscapes: Agrarian, Livestock and Forest Landscapes; Industrial, Infrastructure and Commercial Activities Landscapes; Urban, Historical and Defensive Landscapes and Symbolic Landscapes), as they are defined in the National Plan. This definition is applied to different winemaking areas such as the Ribeira Sacra in Lugo and Orense (Galicia) and the Geria in Lanzarote (The Canary Islands). There is a close relationship between the cultural landscape and the territorial identity in these landscapes, which can also be found in the vineyards of Castilla-La Mancha. Territorial identity is understood as the sense of belonging to a community that has its own characteristic features, and it places people (society) at the centre of the discourse. This connection between territorial identity and the territory itself means that the area and its landscapes are connected by their shared heritage, highlighting the fact that landscapes play "an important role in the formation and consolidation of territorial identities" [27] (p. 123). Therefore, from a geographical perspective, territorial identity is a representation of territorial reference that nurtures territorial anchoring and refers to the specificities of each territorial space. This is fundamental to both the internal and external processes involved in the construction of places.

In this context, analysing the landscape in an identity-based manner means approaching the concept of "place", even the "spirit of a place", as "the landscape only exists in relation to humans, to the degree that they perceive it and appropriate it $[\ldots]$, the landscape is connected to a place and personalised by that place" [27] (p. 124). Implicit in the sense of place are the set of common and shared experiences based on the social relations that develop in place, and which are influenced by history, culture, spatial location, landscape and economic factors [28] (p.86). The vineyard landscapes in Castilla-La Mancha are an accurate expression of this idea, as the people who work in them and inhabit them are closely connected to the cultivation of the vines and the traditions associated with local folklore, as illustrated by the grape harvest (Figure 3). In other words, there is a connection with a tangible and intangible heritage that should be valued, and which forms the basis of collective memory.

The conservation and protection of these resources is an essential aspect of sustainability, as they guarantee the conservation of European values and the continuity of traditions and knowledge for future generations. This provides a context in which cultural values are closely bound to identity. These cultural values include artistic, literary, audio-visual and architectural creation; creative work; contemporary culture; crafts; folklore; archaeological, historical, religious and ethnographical heritage; dialects; music; food and gastronomy; landscapes and natural characteristic features; traditional experience and knowledge; know-how and living traditions [29]. 


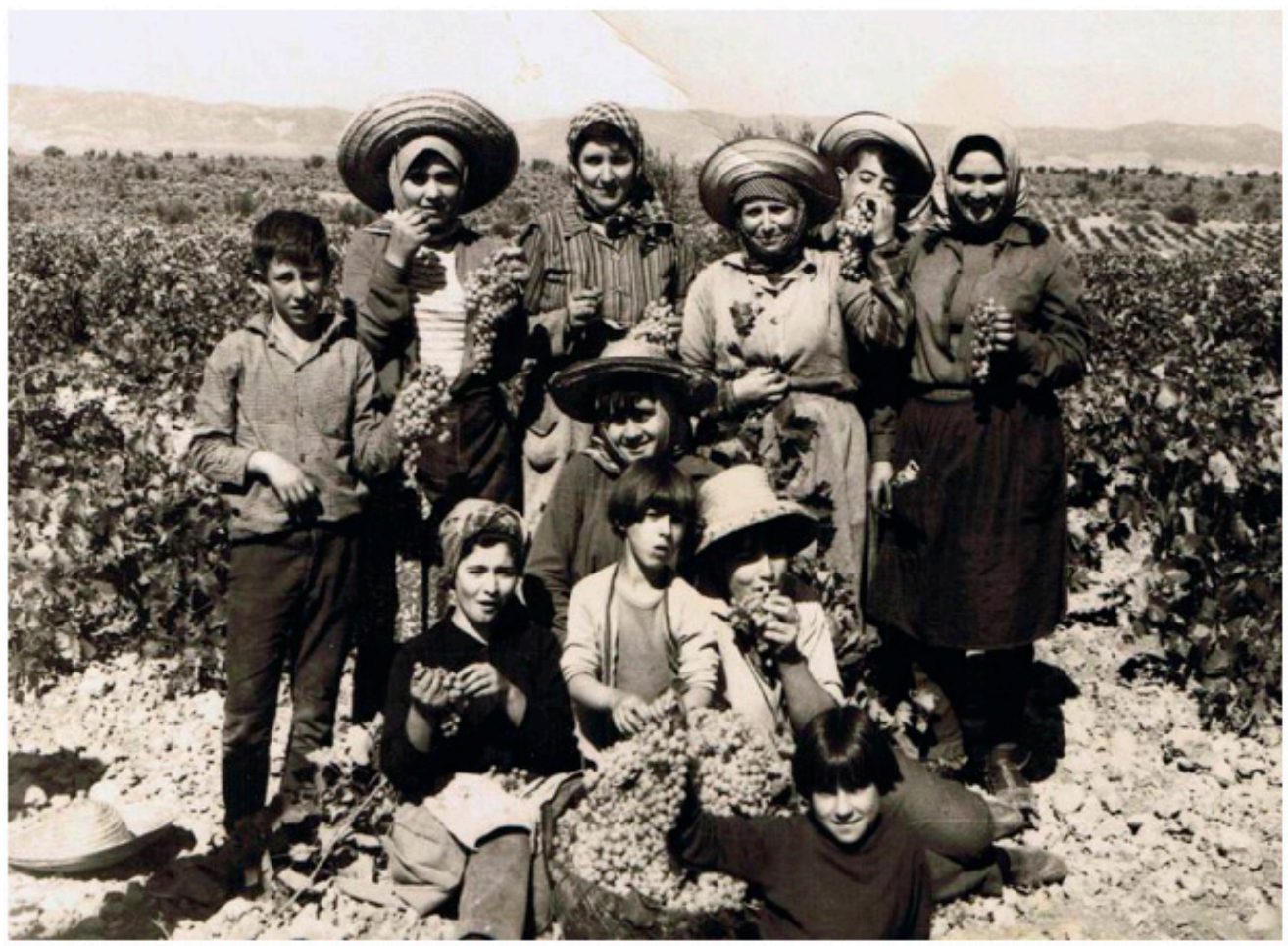

Figure 3. A break in the wine harvest (La Mancha). Files J.F. Santos (1960).

Even though identity is related to the potentialities of a specific territory which is essential for the implementation of developmental strategies, it is sometimes even more closely related to the deterioration, and even the loss, of the "spatial anchors" that emotionally connect people to their birthplaces or places of residence [30] (p. 136). This has often resulted in social movements that have spoken out against the changes that can cause a loss of landscape quality [31] (p. 174). Currently, the proper protection, organisation and management of the landscapes is essential, even though the first step is to recognise their value correctly, which does not always happen.

In our study, we focus on the valorisation of intangible resources, in other words, on the resources that make up "intangible cultural heritage". This heritage includes uses, representations, expressions, knowledge and techniques, along with the instruments, objects, artefacts and cultural spaces that are inherent parts of these. Communities, groups and, in some cases, individuals recognise these aspects as an integral part of their cultural heritage [32]. The heritage resources included in the Convention for the Safeguarding of Intangible Cultural Heritage (2003) are passed down from generation to generation. They are constantly reconstructed by communities and groups in accordance with their surroundings and the way these interact with nature and history. This provides a feeling of identity and continuity, which contributes to the promotion of respect for cultural diversity and human creativity. Some of these resources or assets that are connected to rural areas are recognised on the list of Intangible Cultural Heritage, such as the practice of apiculture in the trees of Belarus (Poland) and the Cherry Festival in Sefru (Morroco).

In Spain, Law 10/215 of the 26th of May for the Safeguarding of Intangible Cultural Heritage focuses on "safeguarding" the practices associated with these assets and bearer communities in order to preserve the conditions of their intrinsic evolutionary process. This process is carried out by passing on information in an intra and inter-generational manner. These practices also have a spatial "locus", but this locus can present general environments and scopes. The bearer community of the culture that integrates these elements and their dynamic character takes priority [33]. 


\section{Materials and Methods}

The methodology used has a direct relationship with the subject matter of our study. We aim to identify the manner in which intangible heritage resources help to reinforce and drive the territorial identity of local communities, and how this favours the multifunctional character of the whole agrarian system. In order to do this, we have taken the Autonomous Region of Castilla-La Mancha as a reference point. This is the main wine producing region in Spain in terms of both spread (cultivated hectares) and production (tonnes) (Figure 4).
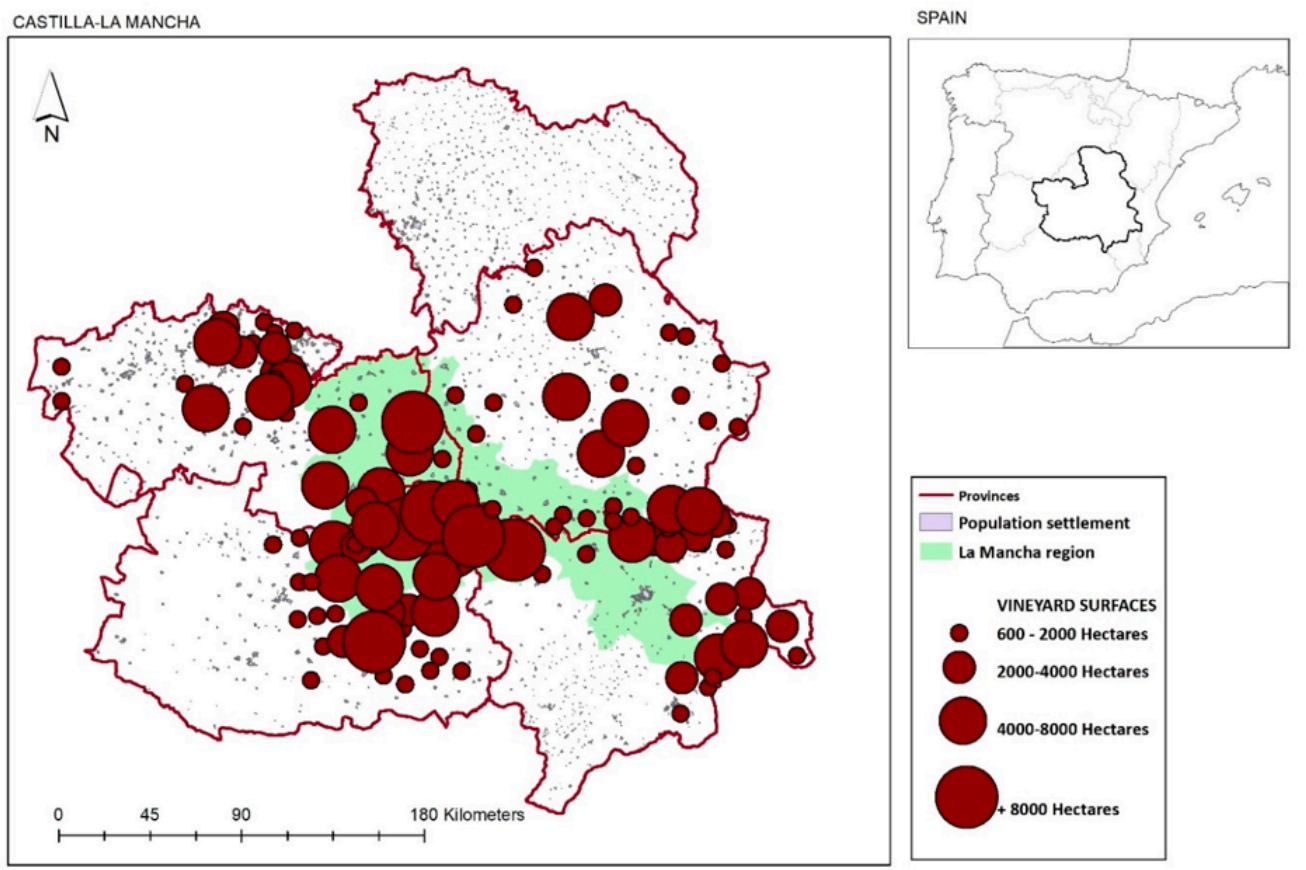

Figure 4. Study area with total vineyard surface areas (2021). Created by the authors.

Around 443,000 hectares of this region were used for the cultivation of vines in 2019, in other words, $47.1 \%$ of the national surface area used for winemaking. Practically all the almost 3.9 million tonnes of production were for must and wine, representing $58 \%$ of the national production total and 53\% of the total export volume according to the Observatorio Español del Mercado del Vino (Spanish Wine Market Observatory) [2]. Geographical factors such as the optimal physical and chemical conditions of the soil and crop adaptation to the climatic rigors of the inland Mediterranean climate-as well as other social and historical factors that we will address later-favour the concentration of this crop in the central area of the region, specifically on the plains of La Mancha.

From a methodological perspective, Figure 5 lists the different stages in which this study is structured. Firstly, vineyard landscapes as multifunctional and territorialised agrarian systems are analysed, as well as their characteristics as cultural landscapes in relation to territorial identity. Secondly, it addresses the characterisation of the intangible heritage resources of the vineyard landscapes that are part the agrarian heritage of the landscapes in Castilla-La Mancha. This characterisation has been carried out by official bodies, such as UNESCO, so that the resources that are associated with the agrarian system of vineyards can be identified. The key step for identifying these resources is to consult the specialised bibliography, the cataloguing carried out by La Carta de Baeza sobre el Patrimonio Agrario (2012) (the Charter of Baeza on Agrarian Heritage) on these types of resources and the Cultural Ecosystemic Services (CES) associated with vineyards, which refers to the intangible benefits that promote spiritual enrichment, cognitive development, reflection and aesthetic and recreational experiences [34,35]. 


\section{OBJECTIVE: $\left\{\begin{array}{l}\text { Intangible resources as elements } \\ \text { of territorial reinforcement }\end{array} \Longrightarrow \begin{array}{l}\text { Territorial and multifunctional } \\ \text { agrarian vineyard systems }\end{array}\right.$}

\section{PHASES OF STUDY:}

1. Conceptualisation (Vineyard landscapes, Intangible Heritage, etc.)

2. Identification of intangible resources $\left[\begin{array}{l}\text { Carta de Baeza } \\ \text { Bibliography } \\ \text { Cultural Ecosystem Services }\end{array}\right.$

3. Folklore and festivals $\left\{\begin{array}{l}\text { Information gathering } \\ \text { Interviews (associations and public institutions) }\end{array}\right.$

Perception about value assigned by

individuals

Economic Impact

Efficiency of institutions

Other territorial aspects

Figure 5. Methodological approach: Phases of study. Created by the authors.

In the third phase of the study, emphasis is placed on the characterisation of some of these heritage resources in vineyard landscapes, such as the celebrations associated with grapevines and wine, focusing on some of the most important ones. In general, these are regularly organised events that represent or highlight a type of culture that is created, repeated and experienced as an expression of heritage [36]. The importance of these activities is analysed in two stages: a first stage in which information is collected from institutions, such as local public authorities, as well as the websites of the agri-food certification authorities and the regional government tourism websites; and a second stage that involves fieldwork that consists of interviews with the people responsible for local groups and public institutions, specifically local government, in order to identify the extent to which these activities are reinforcing territorial identity related to vineyards.

A semi-structured survey was carried out to evaluate the cultural celebrations proposed in recent studies [36], but the survey also incorporates territorial and cultural issues. Therefore, the interview addressed items such as tradition in event organisation; the activities that take place during an event; the frequency of the celebrations; the volume of the population that take part; the aspirations or potential that the events have for tourism; the identification of obstacles or threats to the reinforcement of local identity; and estimations on the efficiency of the institutions and the value that the public confer on these types of events. These phases allow for obtaining extremely interesting information when examining how the sector adapts to the basic principles of a territorialised and multifunctional agrarian system, which goes beyond the inevitable influence of productivism and the commodification of many of its cultural values. In total, 30 interviews were conducted with different local actors, including folklore associations and local councils.

The part of the analysis based on celebrations focuses on all the events that take place in Castilla-La Mancha. In a second stage the initiatives that are to be the subject matter of the interview are selected. The selection was carried out according to two criteria: the tradition of the event and the existence of recent initiatives which represent the production model well. For the first criterion, the Fiestas de la Vendimia y del Vino de Valdepeñas in the municipality of Valdepeñas were selected, which have been held since 1957; for the 
second criterion, the Fiesta de la Vendimia de antaño in Pedro Muñoz was selected, which represents a production model that is very similar to that of other areas with a vocation for winemaking. This second festival has been held fewer than twenty times; in other words, it is a recent event.

\section{Results}

\subsection{Vineyard Landscapes, Culture and Heritage in Castilla-La Mancha}

The concept of heritage has expanded over the last few decades and its values have stopped being interpreted as being is exclusively historical or artistic. Today, heritage covers a wide spectrum of resources inherited from the past which include tangible, intangible and digital (born-digital and digitalised) heritage, including monuments, sites, landscapes, skills, practices, knowledge and expressions of human creativity. It also covers collections that have been preserved and managed by public and private bodies, such as museums, libraries and archives [37]. The territories themselves are now considered as being a legacy or inheritance. A territory can be described as a "non-renewable, essential and limited asset" [26] (p. 2) that has to be passed down to future generations in the best way possible. This is a context in which territories, and therefore their landscapes, must be understood as resources, but also as culture, history, collective memory, identity-based references, public assets, spaces of solidarity and legacy [26] (p. 2).

Agrarian landscapes, specifically vineyard landscapes, are the result of the gradual transformation of a natural landscape by a social group. This transformation is embedded in an area of Mediterranean agrarian tradition, where wine culture is the agent of transformation, the natural space is the vehicle of transformation and the landscape is the result of the transformation. Agrarian landscapes are humanised landscapes in which the revalorisation of culture is embedded in everything that is connected with heritage [38], (p. 138). Therefore, these landscapes are dynamic, and they are the result of the social and economic processes that have always been incorporated. They are also complex, because they integrate natural and anthropic components [39]. These landscapes make an impression that "is not only expressed in the physiognomy of the terrain, but also contributes to defining the character of the people who inhabit it, who use the resources that it offers, and who ultimately, live in it" [40]. (p. 8). Therefore, we are talking about the people who work and live in these landscapes (Figure 6), who perceive them in a unique way, and who find themselves reflected and represented in the tangible and intangible heritage resources, forming a legacy for future generations. Along with the cultural and heritage aspects of the landscapes, we can find an economic factor which is strategic for territorial development. These landscapes also need to be protected, especially those "of great cultural value that are in danger of disappearing, as the evolution of modern vineyards, aesthetically and functionally, has often erased their "traditional" character, which has only been recovered as mere decoration and the memory of a lost past" [41]. (p. 2).

As previously mentioned, since the 1990s, the cultural and heritage dimensions of these types of agricultural landscapes have been recognised by UNESCO through their inclusion on the World Heritage List. We have already highlighted the Italian vineyards, but we must also add the French ones in the Saint Emilion Jurisdiction, in the winemaking area of Bordeaux, the vineyards of the Loire and the vineyard plots (climats) in Burgundy, whose wines are internationally renowned; the Portuguese vineyards in the Alto Douro, where the relationship between territory and winemaking at this river axis is recognised, and the vineyards of Pico on the archipelago of the Azores, which is the only area of grapevines in a volcanic zone; the German agricultural landscape in the Rhineland-Palatinate region, in which the transformation caused by the cultivation of vines on the sides of the Rhin has been recognised; the Hungarian landscape in the Tokaj region, which is an area that combines vineyards and traditional architecture; and the Swiss landscape of the Lavaux region, where the vineyards descend on terraces to Lake Leman. In Spain, the 100 most representative cultural landscapes in the Plan Nacional de Paisaje Cultural include some vineyards, such as those in La Geria on Lanzarote, the Ribeira Sacra in Lugo and Orense (Galicia), which 
were both mentioned earlier, the wine and vineyard landscape in La Rioja, located in Álava and Rioja (the Basque Country and La Rioja), the historical Priorat in Tarragona (Cataluña) and the vineyard landscape in Montilla-Moriles in Córdoba (Andalusia). The tangible and intangible agrarian heritage resources are a part of the identity and memory of the people who work in and inhabit all these landscapes.

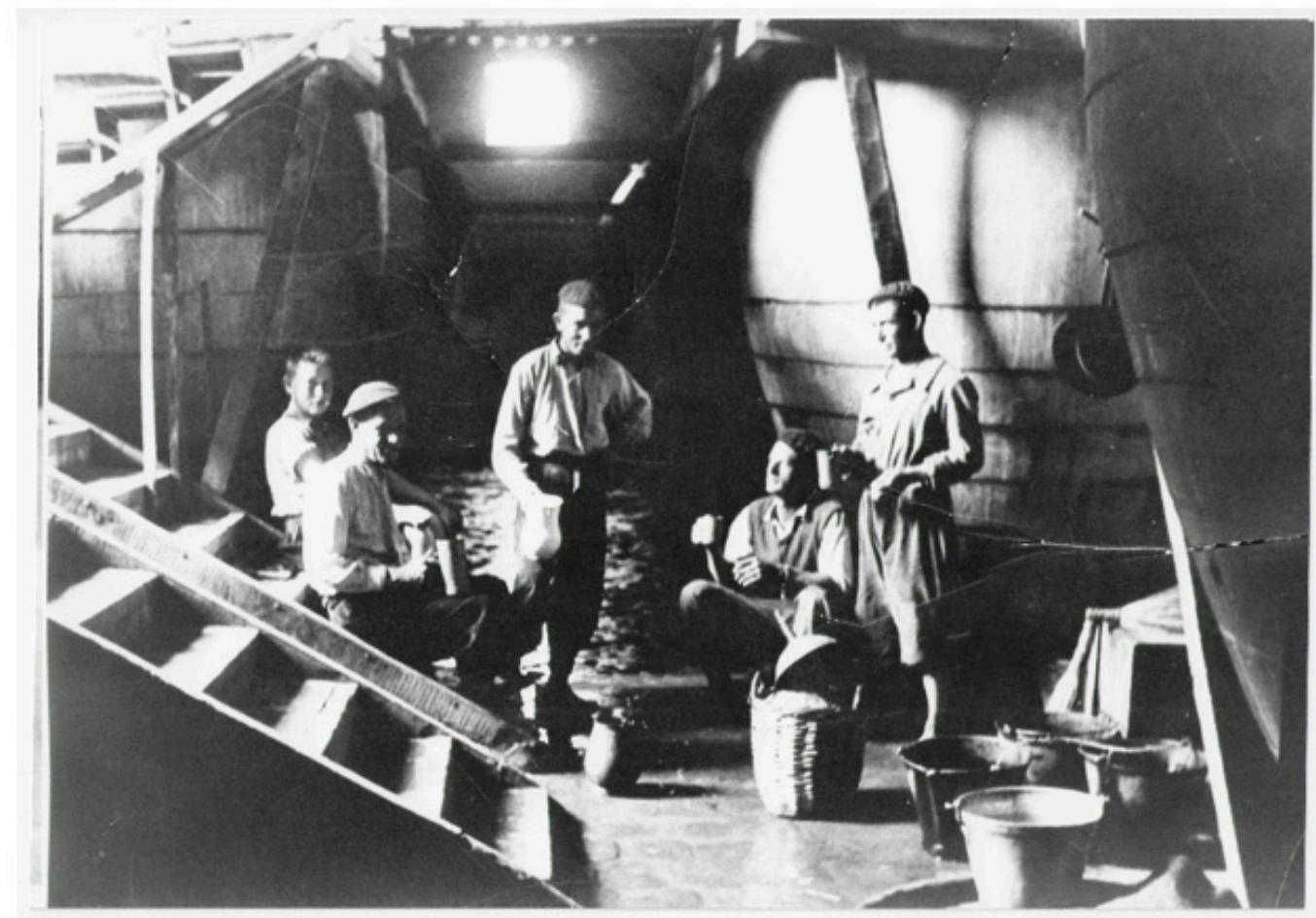

Figure 6. "Stopped on the way for lunch" (Un alto en el trasiego) (Carrizosa, Ciudad Real). Eduardo Matos (1946). Centro de Estudios de Castilla-La Mancha. UCLM. https:/ / www.uclm.es/es/centrosinvestigacion/Ceclm. accessed on 14 December 2021.

According to the methodological diagram proposed in Section 2, when classifying agrarian heritage resources, we use La Carta de Baeza sobre el Patrimonio Agrario [42] as a starting point. This document states the importance of agrarian heritage resources as being representative of the values and the importance of agrarian and livestock activities highlighting the contribution that these resources make to food; their harmonious relationship with the territory, shown in the sustainable and dynamic use of natural resources; their essential identity as a part of the culture-nature relationship and their essential contribution to biological and cultural diversity. This document states that agrarian heritage "is created by the combination of natural and cultural assets, both tangible and intangible, that have historically been generated or used by agrarian activity." Therefore, the document includes moveable assets (utensils, implements and tools used for the farming, transport, storage and manufacture of crops and livestock, documents and bibliographical objects, etc.), unique immovable assets (agricultural buildings and structures that are considered to be unique: country houses, vegetable gardens, agricultural processing plants, grain stores, enclosures, threshing floors, etc.), groups of immovable assets and immovable linear assets (landscapes, rural settlements, irrigation systems, unique agroecosystems, livestock routes, paths, etc.) intangible heritage assets (linguistics, beliefs, rituals and celebrations, knowledge, gastronomy and culinary culture, craft techniques, living treasures, etc.) and natural and genetic heritage assets (local crop varieties, native breeds of animals, seeds, land, vegetation and associated wild animals, etc.). This is heritage that, despite this diversity of elements, has a holistic and integrating character derived from its main constitutive element, which is agrarian activity, understood as a social practice of unquestionable im- 
portance for human development, and that is considered to be a type of heritage that is an indisputably "cultural".

If we refer specifically to the winemaking sector in Castilla-La Mancha, these heritage elements are quite heterogeneous. There are tangible resources; movable assets such as utensils, implements, and tools, presses, earthenware jars, threading machines, etc. There are also elements related to transport (different types of carts), as well as documents and bibliographical objects. Among the unique immovable assets, we can identify assets related to agricultural buildings and structures, such as wine cellars, farmhouses and huts. The groups of immovable assets and immovable lineal assets are part of the vineyard landscapes themselves, especially the traditional vineyards (Figure 7) and the settlements, paths and livestock routes. The intangible elements are mainly related to language, traditions and gastronomy. We will analyse these later, looking at some of the most important issues in depth. The presence of the airén grape in white wines and the tempranillo and cencibel grapes in red wines are outstanding examples of genetic heritage.

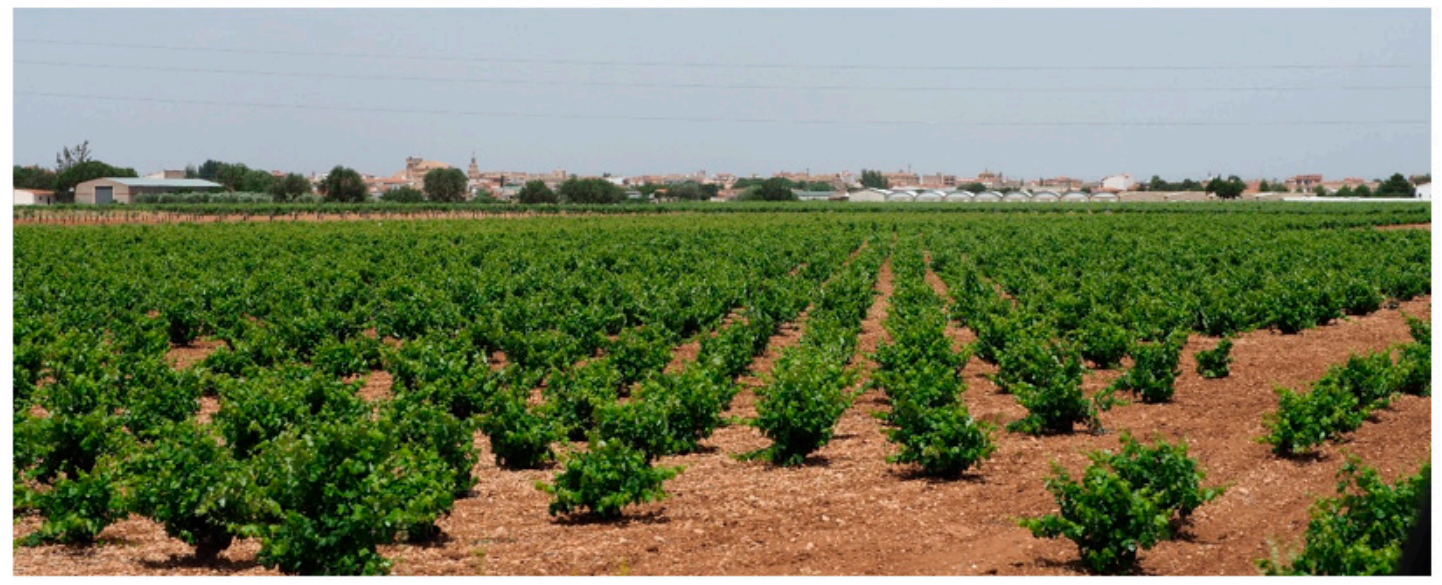

Figure 7. La Mancha vineyard landscape. Source: The authors.

\subsection{Intangible Heritage and Resources in the Vineyard Landscapes in Castilla-La Mancha}

Intangible heritage groups resources together whose heritage values are not tangible. UNESCO describes them as intangible cultural heritage or "living heritage", in other words, the practices, expressions, knowledge and techniques that communities pass down from generation to generation [43]. We can find oral traditions, performing arts, social uses, rituals, celebrations, knowledge and practices related to nature are universally recognised, as well as knowledge and techniques connected to traditional crafts. Despite the fragility of these types of resources, they are sometimes an important factor for maintaining cultural diversity in the face of growing globalisation. Understanding these resources contributes to intercultural dialogue and promotes respect for other lifestyles. Intangible heritage has even been described as "the most important vehicle of cultural diversity" [44]. Generally, the importance of intangible heritage is not its cultural representation but the knowledge and techniques that are passed down from generation to generation. The social and economic value of this inheritance of knowledge is pertinent for both minority and majority social groups, and it is equally important in developing countries and in developed countries. We can clearly associate some of the main characteristics of this type of heritage, as highlighted by UNESCO, with the vineyards of Castilla-La Mancha:

- It is a traditional, contemporary and living heritage, including traditions inherited from the past, but also contemporary rural and urban activities that are characteristic of different cultural groups. Vineyards are examples of these inherited traditions that have adapted to the times. We have chosen the festivals and the cultural acts which accompany these traditions as examples of contemporary uses. 
- It is unifying, as we can share expressions of intangible cultural heritage that are similar to others. This is possible for expressions of intangible cultural heritage from a neighbouring village, from a city on the other side of the world, or an expression of intangible cultural heritage that has been adapted by people who have emigrated to another region. They are all part of intangible cultural heritage; they have been passed down from generation to generation, they have evolved in response to their surroundings, and they contribute to a sense of identity and continuity, creating a connection between the past and the future in the present. Therefore, intangible cultural heritage contributes to social cohesion, encouraging feelings of identity and responsibility that help individuals to feel like members of one or several communities, and society in general. This is something that is intrinsic in wine culture all over the world and it enriches unique local features, as in the case being studied here.

- It is representative, not only as a cultural asset, but also, because of its exclusivity or exceptional value. Intangible heritage flourishes in communities and it depends on them, as local knowledge of traditions, techniques and customs are passed on from generation to generation within each community, or to other communities. Therefore, celebrating festivals for decades, as occurs in different parts of Castilla-La Mancha, obviously contributes to the process of passing knowledge on to future generations.

- $\quad$ Finally, it is based on the community as it is only identified as intangible heritage by the communities, groups or individuals that create, maintain and pass it on. These are the only people who can decide that an expression or a specific activity forms part of their heritage. This "bottom up" creation of heritage is clear in the examples chosen, which we will look at later.

The characterisation of the most important intangible heritage resources that are connected to the vineyard landscapes in Castilla-La Mancha (Table 1) can be added to these definitions, in accordance with the La Carta de Baeza sobre el Patrimonio Agrario. Firstly, we refer to elements (terms) related to language, in other words, unique terms associated with wine culture and the collection of popular proverbs related to wine, which are extremely important in popular tradition. This group includes proverbs, which have deep roots in Spanish culture as phrases of popular origin that have traditionally been repeated, expressing morality, advice or lessons. Secondly, we incorporate beliefs, rituals and celebrations, for example, the Romerías (popular pilgrimages) and the grape harvest festivals. Next, knowledge, trades and traditions, especially those related to harvesting tasks (foundry work, knife and cutlery making, grape harvest, etc.) and gastronomy, including the "know-how" of each dish that accompanies the wine.

The Cultural Ecosystem Services (CES), which are associated with these landscapes, are also especially important. They have been identified in recent contributions [34,35,45-48]. These services promote the spiritual enrichment, mental health, cognitive development, reflection and the aesthetic and recreational experiences of the people who inhabit, work in and enjoy these landscapes. Potentially, all these services can be applied through heritage revalorisation and the development of enotourism. The CES connect the analysis of cultural landscapes that are linked to specific types of activities and processes. The heritage focus, proposed by the CES, includes historical objects and intangible aspects that encourage collective identity [47], symbolising lifestyles that are shared and projected in creative and ceremonial activities and that contribute to human welfare in terms of the identities projected and the experiences derived from these identities [48]. There are services related to heritage that are of aesthetic, recreational, scientific and pedagogical value. These are easily identifiable in the vineyard landscapes. Inspiration, which is identified as a driver for artistic creation (literary, pictorial, etc.) is identified as one of these services, and it is also related to architecture, identity-based symbols and folklore. Inspiration also contributes to the generation of tangible and intangible cultural heritage. 
Table 1. Intangible resources related to vineyards. Created by the authors.

\begin{tabular}{|c|c|}
\hline Intangible Resources & Examples \\
\hline \multirow[b]{2}{*}{ Language } & $\begin{array}{c}\text { Vocabulary: } \\
\text { Atroje (a structure in which products are deposited) } \\
\text { Majano (a pile of stones that mark the borders of plots) } \\
\text { Hilo de pita (a cord to hold objects with) ... }\end{array}$ \\
\hline & $\begin{array}{l}\text { Collection of popular proverbs (literal translation) } \\
\text { "Un buen vino, alegra el ojo, limpia el diente y sana el vientre" } \\
\text { (Good wine brightens the eye, cleans the tooth and heals the belly") } \\
\text { "Por San Blas, empieza la viña a podar" } \\
\text { ("On Saint Blas's day, start pruning away") } \\
\text { "Matrimonio sin viñas, no tendrán sus hijos riñas" } \\
\text { ("A marriage without vines will have children without quarrels")... }\end{array}$ \\
\hline Beliefs, rituals and celebrations & $\begin{array}{c}\text { Fiestas de la Vendimia y el Vino (Valdepeñas) } \\
\text { Romería de la Virgen de las Viñas (Tomelloso) } \\
\text { Romería de San Isidro Labrador (Socuéllamos) ... }\end{array}$ \\
\hline Knowledge, trades and traditions & $\begin{array}{l}\text { Grape harvest, foundry work, knife and cutlery making (utensils and tools), } \\
\text { wicker and esparto (baskets, mats, carry cots) leather (wine skins) ... }\end{array}$ \\
\hline Gastronomy & $\begin{array}{c}\text { Typical dishes: } \\
\text { Gachas (a stew made with grass pea flour) } \\
\text { Migas (breadcrumbs accompanied with back bacon and grapes) } \\
\text { Pisto manchego (made with green peppers, tomatoes and onions) }\end{array}$ \\
\hline Others: Cultural Ecosystem Services (CES) & $\begin{array}{l}\text { Spirituality, tranquillity, aesthetic pleasure, emotiveness, identity, legacy, } \\
\text { existential value, educational value, knowledge, inspiration, etc. }\end{array}$ \\
\hline
\end{tabular}

When applied to the vineyard landscape, the charter is related to different aspects such as movable assets, such as literary and/or pictorial works; unique immovable assets such as traditional agricultural buildings and structures; and especially, the intangible heritage related to the uses and customs based on the traditions of each territory. Spirituality is connected to elements that are considered to be valuable to a community because of their tribal or fetishist significance. It is easy to identify these intangible heritage elements for vineyards, and they are grouped into different categories: beliefs, rituals and celebrations that represent the role of religion in the calendar of saint's days, the festivals which are associated with fertility, and specific festivals that we will cover later.

3.2.1. Social Practices, Rituals and Celebrations Associated with Vineyards: Intangible Resources Creating Territorial Identity in Castilla-La Mancha (Spain)

There are many intangible heritage resources associated with vineyard landscapes in Castilla-La Mancha and we focus on some celebrations connected to the social uses of these resources and the rituals that represent wine culture in this region. There are customs that structure the lives of communities and groups, and theses customs are shared and respected by many of the members of these groups. These customs are important because they reaffirm the identity of those who perform them, whether in a group or socially, or in public or in private. In each case, they are closely linked to significant events. They belong in a group of resources that, according to UNESCO [49], contributes to marking the changing seasons, the periods of agricultural tasks and the stages of human life, and they are intimately related to a vision of the world, history and collective memory. Some examples of these events found in winemaking areas are included on the List of Intangible Cultural Heritage because of their universal value. Examples of these are the old method of traditional vinification in Kvevri, Georgia, the bread and wine festivals held at the end of winter in Geraardsbergen (Belgium), the traditional practice of the cultivation of head-trained bush vines ("vite ad alberello") in the region of Pantelleria (Italy) and the winemakers' festival in Vevey (Switzerland) [50]. 
There are many rituals and festivals held in European winemaking areas that celebrate Bacchus or Dionysus and the harvesting of the vines. Even though these activities have not been recognised for their universal value, they are recognised by the regions or states in which they take place. They are celebrated at specific moments of the year and in specific places, as with the "Beaujolais nouveau" festival that originated in France but is celebrated in 110 countries at the same time, the German Grape Harvest Festival in Neustadt, the Wine Festival in Anhiolos (Greece) and Martinovanje, the celebration of wine culture in different areas of Slovenia. In some cases, these social uses, rituals and events have been seriously affected by the changes that the communities have experienced in modern society, as they largely depend on the participation of individuals who organise them in communities and other community members. Emigration, the development of individualism, the generalisation of formal education, the growing influence of large global religions and other effects of globalisation have had repercussions that are acutely felt in these practices [50].

In Spain, these activities are recognised by law, which safeguards them as a part of intangible cultural heritage in the group "social uses, rituals and celebrations", and there are many activities that take place in the winemaking territories. Some of these activities are the Batalla del Vino (the Wine Battle) in Haro (la Rioja), the Fiesta de la Vendimia (the Grape Harvest Festival) in Lanciego (Rioja Alavesa), the Fiesta de la Vendimia (the Grape Harvest Festival) in Rueda (Castilla y León), the Fiesta del Albariño (the Albariño Festival) in Cambados (Galicia) and the Fiesta de la Vendimia (the Grape Harvest Festival) in Jerez de la Frontera. Castilla-La Mancha has its own examples, such as the Mondas festival in the area of Talavera de la Reina, one of the oldest festivals in Spain celebrating the cult of the goddess Ceres [16] (p. 78). We will continue by looking at two of these festivals in depth. They are the Fiestas de la Vendimia y del Vino (the Grape Harvest and Wine Festival) in Valdepeñas and the Fiesta de la Vendimia de Antaño (the Traditional Grape Harvest Festival) in Pedro Muñoz, both in the province of Ciudad Real. Other important festivals also exist in this region, such as the Fiestas del Vino (Wine Festivals) in Tomelloso (Ciudad Real) in honour of its patron, the Virgin of the Vines; Manchavino, La Mancha International Wine Festival in Socuéllamos (Ciudad Real), the Fiesta de la Vendimia (the Grape Harvest Festival) in Villarrobledo (Albacete), the "Fiesta de la Vendimia. El sentido de nuestra tierra" (the Grape Harvest Festival. The meaning of our land") in Villarrubia de los Ojos (Ciudad Real), the Fiesta de la Vendimia (the Grape Harvest Festival) in Campo de Criptana (Ciudad Real), the Pandorga in Ciudad Real, where one day is dedicated to "zurra", a special local drink, and the Feria Medieval del Vino DO Méntrida (the Medieval Wine Fair, DO Méntrida) in Montearagón (Toledo). All these celebrations share a wine culture in common even though each one is marked by its unique local character.

The heritage values of each of these celebrations provide an obvious boost to the reinforcement of identity and to the potential inclusion of these celebrations in territorial development strategies, as the examples chosen show. We believe that the grape harvest festivals are the celebrations that best embody the spirit of Castilla-La Mancha, and we will proceed to describe two of the most important celebrations in the region. The first of these is a celebration that has been held for the last seven decades, while the second example is more recent:

1. The Fiestas de la Vendimia y del Vino de Valdepeñas (Ciudad Real) are some of the most important festivals in Castilla-La Mancha, and they have been declared as being of "tourist interest". They have been taking place since 1953 in Valdepeñas, which is one of the most important areas of DO in Spain. They were preceded by the Feria Nacional del Vino (the National Wine Fair), which had a commercial focus and was held in 1952 [16] (p. 85). These celebrations currently include numerous activities related to wine culture, culminating in a verbena (a popular celebration with dancing) for the public in Plaza Mayor (Figure 8). Several of these activities are particularly interesting, such as the International Exhibition of Visual Arts (which awards a gold medal for art) dedicated to painting. This is accompanied by the Street Painting Competition and the Open-Air Painting Exhibition; the folk festival 
called "The City of Wine". The inauguration of this event includes the treading of the first must from the recently harvested black and white grapes. This has been held since 1986 and is performed as an offering to the Virgin of Consolation, who is the Patron of the city. Other events are the floral offering to the Virgin and different liturgical acts, wine tasting, the regional competition of "Limoná" (lemonade) and the gastronomic competition of typical dishes [51]. The National Gathering of Musical Bands "The City of Wine", also takes place, which brings together different bands that march through the streets of the city, as well as the Wine Festival Poetry Recital, which has recently grown in importance. The Brindis Poético, literally the "Toast to Poetry", takes place, and the prize for the Wine Harvester of the Year is given. The European Day of Enotourism, which is celebrated on the first weekend in November is another event which reinforces the image of the culture associated with the vineyard landscape in this area.

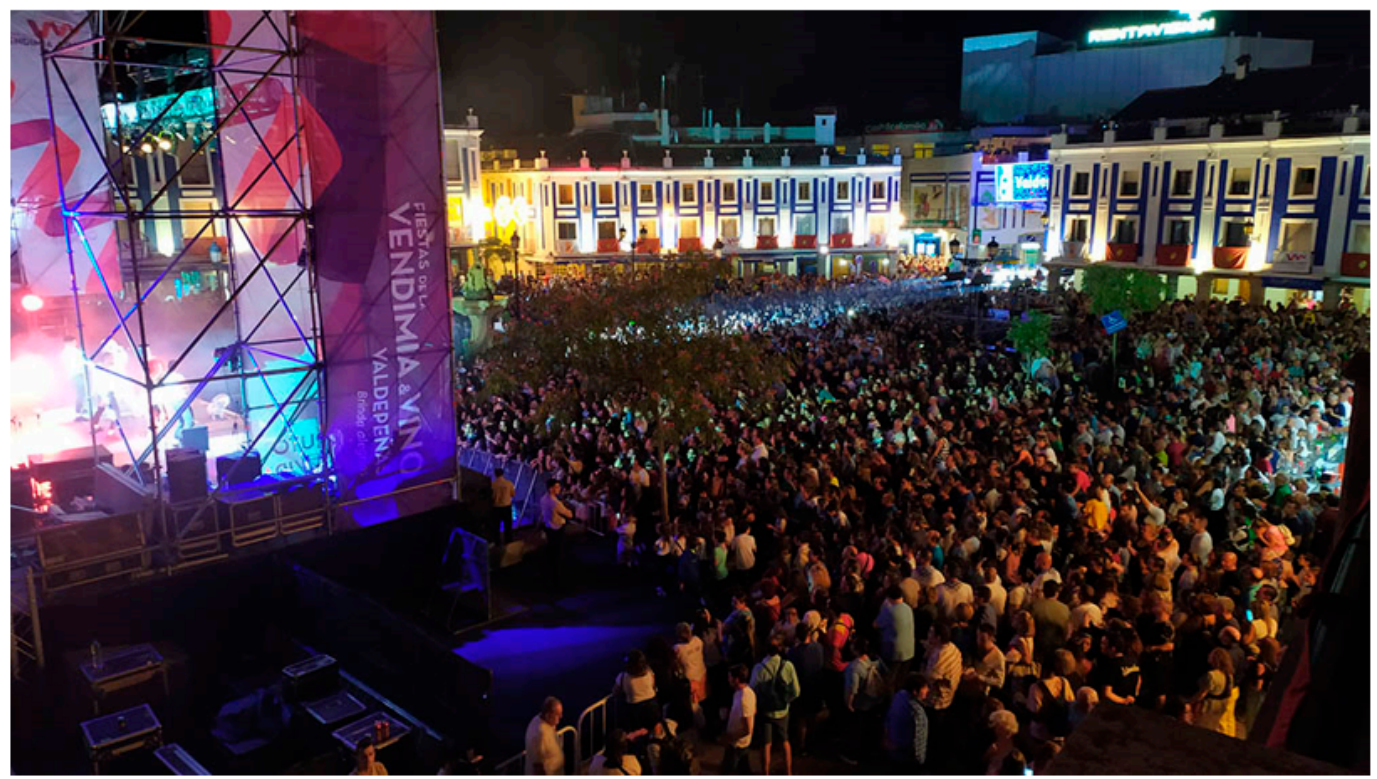

Figure 8. Fiestas de la Vendimia y el vino en Valdepeñas (Wine Harvest Festival). Valdepeñas City Council (2018).

By promoting wine culture in Valdepeñas and passing on its traditions, the activities organised by the different associations and collectives in the city also play an important part. Some of the groups who are involved are the literary and artistic Group, El Trascacho (they organise poetry competitions, gatherings and literary get-togethers) and the Desde el Empotro-Fundación Grupo A7 group. Different activities connected with the revalorisation of agricultural buildings and structures and intangible heritage take place with guided excursions to wine cellars and events connected with the regional gastronomic values, as well as collaboration with other public and private entities and educational activities, especially in schools. The Asociación Jóvenes Amigos del Vino de Valdepeñas (Valdepeñas Young Friends of Wine Association), the Asociación El Trascacho (the Trascacho Association) and the Cofradía de los Mayorales del Vino (the Brotherhood of Wine Overseers) have created these activities. The fairs in which the Valdepeñas DO is present, such as FITUR (International Tourism Fair) and FENAVIN (National Wine Fair) deserve a separate, complementary chapter [52].

These festivals receive major institutional support, from the City Council and from the commitment made by several local associations and businesses. This support is accompanied by an enormous involvement of locals, which contributes to the success of these events. The cultural weight of some of these activities, such as the Poetry Festival and the Flamenco Festival, reinforces the importance of the celebrations, which after years of consolidation are not under threat. 
2. The Fiesta de la Vendimia de Antaño has been held in the municipality of Pedro Muñoz (Ciudad Real) since 2005, and it is an excellent example of local participation and initiative. The origin of this celebration arose from the heart of the local folk association. This association is supported logistically by the local government, who signed an agreement to collaborate with them every year. This agreement also states that other local festivals with strong territorial roots such as La Fiesta del Mayo Manchego, held on the 1st of May, are also recognised as being events of national tourist interest. The grape harvest festival, which is usually held at the beginning of September, is also supported by the local agrarian cooperative, whose products are on offer on the day of the festival, as well as other regional agri-food organisations with certifications or quality marks, such as the La Mancha DO. There are three main activities at the festival which are the best examples of how the celebration reinforces the territorial identity of the community. First is the traditional grape harvest, which is carried out using utensils and traditional harvesting techniques, with carts pulled by mules and esparto containers (seras/baskets). Second is the parade of around 2000 people that crosses the municipality; in other words, a quarter of the local population is directly involved in the celebrations. The people who take part in the parade are encouraged to dress in the typical local outfits that their ancestors would have worn. These outfits include elements of local identity such as abarcas (typical footwear made from esparto), traditional scarves, blouses and trousers. The traditional drink, called zurra, which is made with white and red wine, sugar and soda water is enjoyed and there is also a parade of antique carts, tractors, trailers and draught animals, such as mules. Finally, in the third main activity, a stage is constructed on which the ceremony of the first treading of the native variety of grape takes place (Figure 9), and several regional dance groups give performances. The festival also includes other activities, and all the celebrations culminate in a verbena.

When planning the festival, the organisers recognise the institutional collaboration, the wide local acceptance and the interest of the organisations involved in agri-food production. Through local and regional consolidation, this celebration has become an event that has received regional and national recognition. A local group also carries out local awareness work with its own dance school and work with local schools.

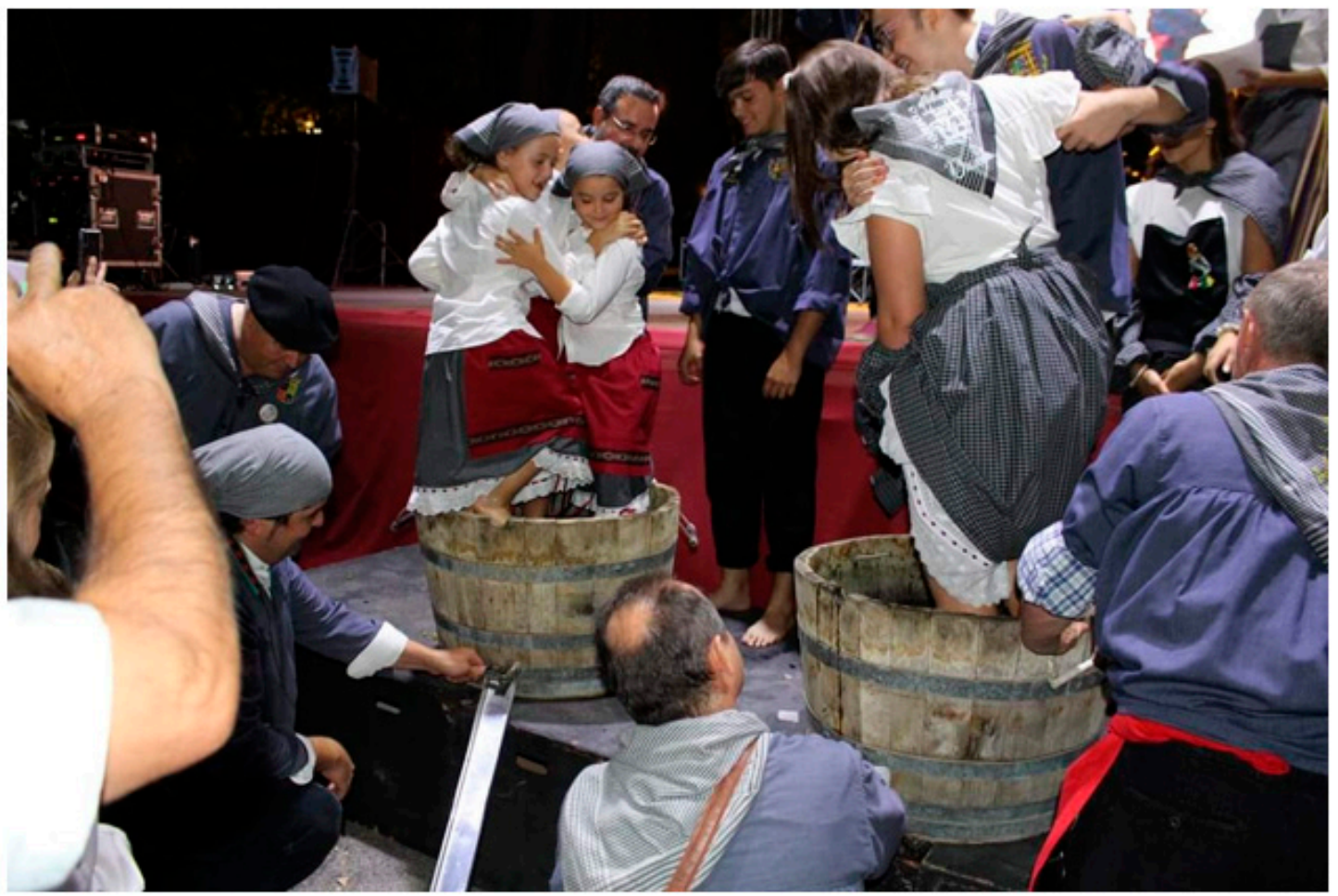

Figure 9. Vendimia de antaño Festival in Pedro Muñoz (2019). Source: Ángel Escudero. 


\subsubsection{Intangible Resources and Multifunctionality: Wine Tourism}

The promotion of some of the heritage resources mentioned has facilitated the development of wine tourism or enotourism in these areas and others. This specific form of tourism, also known as enological tourism, and even eno-gastronomy [10] (p. 557, et seq), responds to the new demands for cultural tourism and the marketing strategies and economic diversification of wineries [53]. The identity-based value of wine culture, in this case in Castilla-La Mancha, is directly related to the development of this tertiary activity, which is generating new employment and diversifying local economies. The recent intensification of this type of tourism has been connected with an improvement in the quality of the wines, as reflected by the different DOs, the vineyard landscapes and their unique buildings (mainly wineries), as well as gastronomy. In other words, we can discover a connection with cultural and historical elements that are a "clear reflection of the identity of a geographical area" [54] (p. 218). Economically, it is an activity that is based on trips motivated by the appreciation of the flavour and aroma of wines and the traditions of the places that produce them [55] (p. 315). It is a complement to high-quality tourism [56] (p. 734), which can be the main attraction when visiting a region. Furthermore, this sector is operating as a driver of economic reactivation. Some vineyards in winemaking areas that are less economically developed, but have a high concentration of heritage assets, are receiving greater recognition and are being valued more highly. An example of this phenomenon is the winemaking area of Duero, [57] (p. 97).

In Castilla-La Mancha, the quality of traditional agri-food products (wine, cheese, olive oil, aubergines, purple garlic, etc.) has improved greatly, and this is also true of their wines over the last few decades. These wines have faced stiff competition from the wines of other regions that have a more classic and traditional approach to the product. However, the wines from Castilla-La Mancha offer good value for money, and its young wines and crianza wines are most highly recommended. The region boasts traditional varieties of both white (Airén) and red (Cencibel) wines, and this red grape has been combined with other foreign varieties (Cabernet Sauvignon, Merlot, Syrah) that are planted on trellises and have drip irrigation systems [56] (pp. 732-733); in this sense, the latest Common Market Organisations for wine (1999 and 2008) have determined the expansion of these nonindigenous varieties, which are increasingly in demand in international markets. Public and private initiatives have arisen around this wine culture, and we will consider some of them, such as the Ruta del Vino de La Mancha (the La Mancha Wine Route), presided over by the municipality of Alcázar de San Juan, and the route includes Alcázar de San Juan, Tomelloso, Campo de Criptana, Socuéllamos, El Toboso and Villarrobledo [58]. There are also numerous wineries that individually organise tourist visits that are generally accompanied by wine tasting, such as those at Pago del Vicario in Ciudad Real, Finca la Estacada in Tarancón, Castiblanque in Campo de Criptana and Pago Guijoso in El Bonillo.

The development of enotourism can also been seen in Valdepeñas. It has been included on the Ruta del Vino de Valdepeñas (the Valdepeñas Wine Route), one of the Spanish wine routes, and promoted by the regional government, along with the municipalities of Alcubillas, Moral de Calatrava, San Carlos del Valle, Santa Cruz de Mudela, Torrenueva, Torre de Juan Abad, Granátula de Calatrava, Alhambra and Montiel [59]. It is also home to the Museo del Vino (Wine Museum), which is another reason why this city is an attractive destination for people interested in this type of tourism. The museum is in an old winery, which belonged to Leocadio Morales (1901), one of the wineries that experienced the boom in the commercialisation and exportation of wine from Valdepeñas at the beginning of the last century (Figure 10). In this museum, visitors can discover the evolution of the cultural practices related to grapevines and the creation of the Valdepeñas DO wines, as well as numerous examples of tangible heritage (implements and tools, machinery, transportation carts, earthenware jars, etc.). 


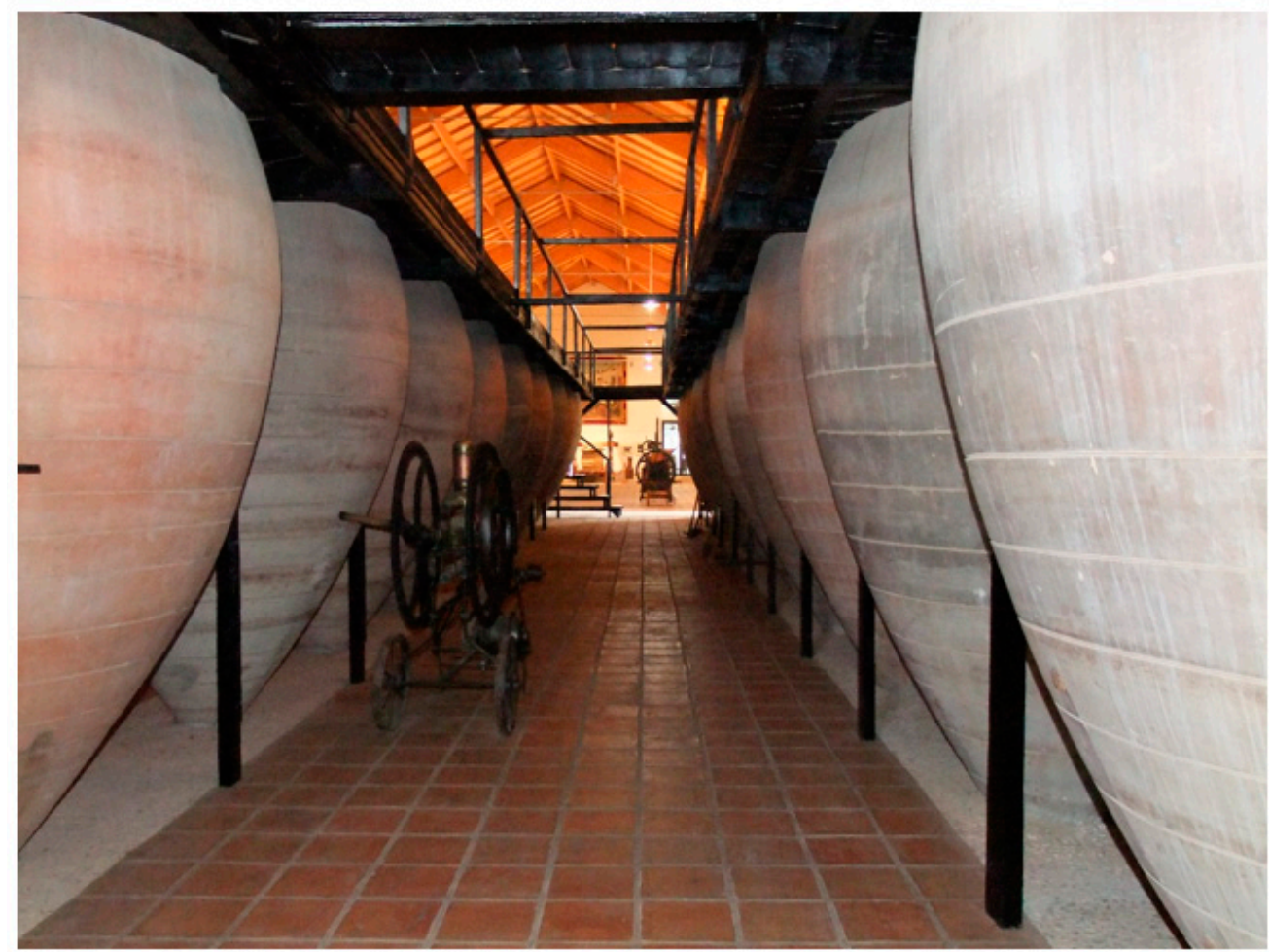

Figure 10. Valdepeñas Wine Museum. The Authors.

Finally, Valdepeñas also celebrates the European Day of Enotourism, which was last held from the 4 th to the 7 th of November with conferences and other activities. There were visits to different local wineries, such as the traditional winery of Navarro López (1904), in which the traditional form of Valdepeñas winemaking was demonstrated. This was accompanied by a tasting session with pairings of "Nacarro" and "1904" vermouths. The Arúspide winery had a guided route with an explanation of the winery and the creation of its wines, as well as a wine tasting session. The old Los Llanos winery offered a walk through its traditional caves that have housed wine from Valdepeñas and a wine tasting session.

\section{Discussion}

The organisation of events and festivals related to an agrarian activity is inevitably connected to the interpretation of the tradition and local community awareness. The resulting celebrations reinforce the territorial character of land use (cultivation of grapevines) by consolidating local identity and favouring agrarian multifunctionality. Even though the practices associated with winemaking are over a century old, this territorial and multifunctional character is only starting to become significant in the festivals that are currently being organised. Despite this relative delay in recognition, we have to positively value the fact that these types of processes have begun within production structures that are anchored in strictly productivity-focused dynamics. Some of the key elements of this revalorisation process will be detailed later.

Firstly, in the context of vineyard landscapes and their associated heritage resources, the valorisation of these landscapes as cultural landscapes must be considered as a reference of the post-productive transition. These are landscapes that have now become revalorised through the organisation of tourist activities focused on routes or circuits [60]. Secondly, we must stress the importance of intangible resources, many of which have been recognised as examples of heritage by official institutions, which is top-down recognition. Public recognition is also important: people see themselves reflected in the landscapes, in other words, through bottom-up recognition. These heritage resources or assets are obviously 
a part of the cultural heritage that has been revalorised and connected with territoriality and the identity of places and their people over the last few decades. In Europe, this heritage is a source of memory, identity and cohesion, and it has great societal value from cultural, environmental, social and economic perspectives. As a result, this heritage has been converted into an asset or a series of assets. These are social alternatives to the developmentalist economism of our time, and therefore it is imperative that they are conserved, protected and promoted [61]. The European Council refers to this heritage, stating that its "sustainable management is a strategic option for the twenty first century" [62] (p. 36).

This general heritage has been ignored for a long time, but it is now recognised thanks to the conceptual and legal changes which have led to a move from a strictly regulatory focus to one that is less restrictive. This new focus considers the capacity that objects have to awaken certain values that help society to consider them as examples of heritage [63]. Currently, in the era of globalisation, many forms of this type of heritage are in danger of disappearing, threatened by the displacement of villages, caused by political and socioeconomic instability, the deterioration of the environment, the uncontrollable development of tourism, cultural standardisation, armed conflicts, industrialisation, as well as the accelerated processes of change, urbanisation and acculturation [64]. These are all reasons that reinforce the need for the protection and conservation of heritage.

With intangible heritage resources, we can focus on factors such as self-recognition by the communities, groups and individuals involved in their cultural heritage; constant reconstruction as a response to the historical and social evolution of communities and groups; the deep-rooted connection of heritage with the identity of its creators and bearers; "authenticity" as an implicit requirement; and the enormous crossover of these resources with human rights. Human rights can be considered from two perspectives: human rights standards as a parameter for the legitimacy of the heritage in question, and the use of heritage as a tool to promote the effective enjoyment of these rights [44] (p. 108).

The celebrations associated with the agricultural activities discussed in this article are an example of many similar activities that take place on the Iberian Peninsula [65], where events such as offering and obtaining the first must are essential activities that have later been diversified. One of the main reasons that these events are successful is the level of institutional collaboration and management [36]. In the cases presented in this article, we have shown how local groups play an essential role, and their work is sponsored and supported by local public authorities and other institutions from the production sector. The fact that the organisation is based on local groups restricts any type of external interference or commercialisation of the heritage assets that constitute a specific territory. An example of this type of organisation can be found in Valdepeñas, where the Fiestas del Vino y de la Vendimia are supported by the initiative of local institutions (City Council) and the support of influential local associations related to wine culture and the active presence of the main wineries of the Valdepeñas DO, which represent the private sector. In Pedro Muñoz, we have seen that the folklore group is in charge of the whole event, meaning that the members of this group are responsible for the ideas that promote the event and guarantee that future events can be held. These members altruistically make an effort to recover and value the memory of their ancestors. These celebrations do not receive the same volume of tourists or have the same number of activities as other similar international festivals [66,67], but they do have institutional support that respects bottom-up decision-making processes and supervises collaboration between local groups and the local and regional production network. As a consequence, the representations and expressions that form a part of their cultural heritage are converted into territorial assets that are defined at a micro scale [68]. These assets have an identity-based value which is attributed by the local community, and within the community this intangible heritage acts as a vector for the creation of heritage at a perceptive scale. We have also shown that the wine festivals (games, dances, processions, offerings, etc.) are a way of defending and remembering old traditions in the twenty first century, but they are also an important marketing instrument that can act as regional advertisements for enotourism [16] (p. 86). 
We reaffirm the hypothesis that the revalorisation of these types of resources by local communities and institutions favours economic diversification and, as a consequence, the multifunctional character of land use, by considering its potential use for tourist activities. Equally, we consider that public support and participation is essential for safeguarding and maintaining this heritage for future generations, reinforcing the territorial identity that we proposed as our research question.

Furthermore, as representative elements of the cultural heritage of the winemaking territories, the valorisation of these resources and their inclusion in development strategies is connected with the attainment of some of the Sustainable Development Objectives included in the United Nations Agenda 2030 for Sustainable Development. This recognises global citizenship, cultural diversity and intercultural dialogue as general principles of sustainable development. Culture is explicitly mentioned in several of these objectives, in particular in Objective 11 (cities), Objective 4 (education), Objective 8 (sustainable growth), which is related to tourism, and Objective 12 (consumption) [69]. We consider that these last two objectives are directly related to intangible cultural heritage resources, such as the festive events associated with wine culture that we have analysed here.

\section{Conclusions}

The organisation of events that promote the recognition of traditional knowledge are an unmistakable sign of the revalorisation of intangible heritage, which helps specific territories to work on new forms of rural resilience and development. When these events arise from the joint work of the public sector (municipal corporations, regional corporations, etc) and the private sector (the local population, cultural associations, companies, etc.), two important issues are addressed: firstly, that these festive events favour the revindication of the cultural roots of a community, and that they are expressions of territoriality that construct the identity of a population or social group that has transformed a territory in order to survive in it; and secondly, that these activities contribute to reinforcing the multifunctional character of winemaking, given that the valorisation of the intangible and tangible heritage that is promoted by these types of initiatives drives economic diversification by creating new tourist interest. For agrarian cultural landscapes, specifically vineyard landscapes and their associated agrarian heritage, we have been able to illustrate both of these issues with the Fiestas de la Vendimia y del Vino de Valdepeñas and the Fiestas de la Vendimia de Antaño de Pedro Muñoz, which are examples of the enormous wealth of intangible cultural heritage related to wine culture in the region of Castilla-La Mancha (Spain).

Author Contributions: Introduction, Á.R.R.P. and M.d.C.C.R.; methodology, Á.R.R.P. and M.d.C.C.R.; results, discussion and conclusions, Á.R.R.P. and M.d.C.C.R.; writing and revision of the manuscript, Á.R.R.P. and M.d.C.C.R. All authors have read and agreed to the published version of the manuscript.

Funding: This research was funded by the Ministry of Science and Innovation, National Plan 2019. Project: Multifunctional and territorialised agri-food systems in Spain. Conceptualisation and governance. Analysis of cases in Madrid and Castilla-La Mancha. ID2019-105711RB-C61/AEI/ $10.13039 / 50100011033$.

Informed Consent Statement: Informed consent was obtained from all subjects involved in the study. Written informed consent has been obtained from the patient(s) to publish this paper.

Acknowledgments: The authors would like to thank the Municipal Council of Valdepeñas, the Municipal Council of Pedro Muñoz and the Folklore Association of "Virgen de los Ángeles" of Pedro Muñoz for their collaboration.

Conflicts of Interest: The authors declare no conflict of interest. 


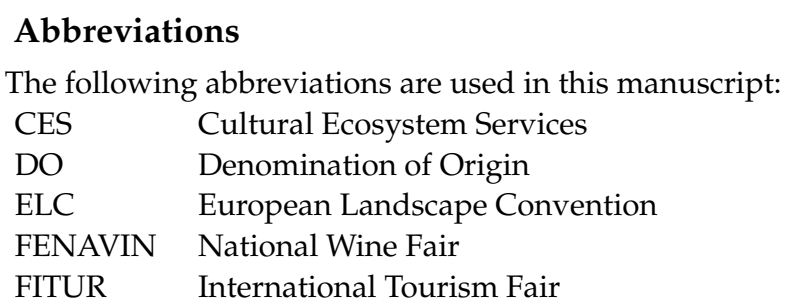

\section{References}

1. Unwin, T. Wine and the Vine. A Historical Geography of Viticulture and The Wine Trade; Routledge: London, UK, 1991.

2. OEMV (Observatorio español del mercado del vino). Exportaciones vitivinícolas por Comunidades Autónomas y por Provincias 2000-2020. 2020. Available online: https://oemv.es/exportaciones-vitivinicolas-por-comunidades-autonomas-y-provinciasano-2020 (accessed on 8 December 2021).

3. Guijoan, E.; Badía, A.; Tulla, A. El nuevo paradigma de desarrollo rural. Reflexión teórica y reconceptualización a partir de la Rural Web. Bolet. Asoc. Geógr. Españ. 2016, 71, 179-204.

4. $\quad$ Ilbery, B.W.; Bowler, I.R. From agricultural productivism to post-productivism. In The Geography of Rural Change; Ilbery, B.W., Ed.; Prentice Hall: London, UK, 1998; pp. 57-84.

5. Wilson, G.A. From productivism to post-productivism and back again? Exploring the (un)changed natural and mental landscapes of European agriculture. Transact. Instit. Brit. Geograph. 2000, 2, 77-102.

6. Armesto, X.A. Notas teóricas en torno al concepto de postproductivismo agrario. Investig. Geogr. 2005, 36, 137-156. [CrossRef]

7. Mather, A.S.; Hill, G.; Nijnik, M. Post-productivism and rural land use: Cul de sac or challenge for theorization? J. Rural Stud. 2006, 22, 441-455. [CrossRef]

8. Evans, N.; Morris, C.; Winter, M. Conceptualising agriculture: A critique of post-productivism as the new orthodoxy. Progr. Human Geogr. 2002, 26, 313-332. [CrossRef]

9. Wilson, G.A.; Burton, R.J. Neo-productivist agriculture: Spatio-temporal versus structuralist perspectives. J. Rural Stud. 2015, 38, 52-64. [CrossRef]

10. Plaza, J.; Cañizares, M.C.; Ruiz, A.R. Patrimonio, viñedo y turismo: Recursos específicos para la innovación y el desarrollo territorial de Castilla-La Mancha. Cuadernos Turismo 2017, 40, 547-571. [CrossRef]

11. Gilg, A.W.; Battershill, M. Quality farm food in Europe: A possible alternative to the industrialised food market and to current agri-environmental policies: Lessons from France. Food Policy 1998, 23, 25-40. [CrossRef]

12. Grunert, K.G. Food quality and safety: Consumer perception and demand. Eur. Rev. Agric. Econ. 2005, 32, 369-391. [CrossRef]

13. Arce, T.K.; Marsden, A. Constructing quality: Emerging food networks in the rural transition. Environ. Plan. 1995, 27, 1261-1279.

14. Ilbery, B.; Knefasey, M. Producer constructions of quality in regional speciality food production: A case study from south west England. J. Rural Stud. 2005, 16, 217-230. [CrossRef]

15. Plaza, J.; Ruiz, A.R. Distintivos de calidad alimentaria en Castilla-La Mancha y problemas en la gobernanza territorial. Desenvolv. territ. Debate 2015, 5, 48-70.

16. Negrín de la Peña, J.A. Las fiestas del vino en La Mancha: Folclore e identidad. RIVAR 2021, 8, 71-89. [CrossRef]

17. Del Canto, C. Nuevos conceptos y nuevos indicadores de competitividad territorial para las áreas rurales. Anal. Geogr. Univ. Complut. 2000, 20, 69-84.

18. Hamdouch, A.; Depret, M.-H. Sustainable development policies and the geographical landscape of the green economy: Actors, scales and strategies. Finisterra 2013, 47, 49-80. [CrossRef]

19. Scott, M. Resilience: A Conceptual Lens for Rural Studies? Geogr. Comp. 2013, 7-9, 597-610. [CrossRef]

20. Sánchez, P.; Gallardo, R.; Zamora, F. La noción de resiliencia en el análisis de las dinámicas territoriales rurales: Una aproximación al concepto mediante un enfoque territorial. Cuad. Desarro. Rural. 2016, 13, 93-116. [CrossRef]

21. Pinchemel, P.H. Fines y valores de la educación geográfica. In Nuevos Métodos Para la Enseñanza de la Geografía; Graves, N., Ed.; Teide: Barcelona, Spain, 1989; pp. 7-21.

22. UNESCO. Paisajes Culturales. Available online: https:/ / whc.unesco.org/en/culturallandscape (accessed on 7 November 2021).

23. IPCE (Instituto del Patrimonio Cultural de España). Plan Nacional de Paisaje Cultural. Available online: http://www. culturaydeporte.gob.es/planes-nacionales/planes-nacionales/paisaje-cultural/definicion.html (accessed on 5 May 2021).

24. CEP (Convenio Europeo del Paisaje), Florencia, 2000. Available online: https://www.mapa.gob.es/es/desarrollo-rural/planes-yestrategias/desarrollo-territorial/090471228005d489_tcm30-421583.pdf (accessed on 23 December 2020).

25. Cañizares, M.C. Procesos y retos en torno al patrimonio y a los paisajes culturales: Una reflexión teórica desde la geografía española. Rev. Geogr. Norte Grande 2020, 76, 189-212. [CrossRef]

26. AGE y Colegio de Geógrafos. Manifiesto por una Nueva Cultura del Territorio, 2006. Available online: https://www.agegeografia.es/site/wp-content/uploads/2018/10/Manifiesto-por-una-nueva-cultura-del-territorio-2006.pdf (accessed on 18 October 2021).

27. Nogué, J. El retorno al paisaje. Enrahonar 2010, 45, 123-136. [CrossRef] 
28. Ramos, S.L.; Feria, Y. La noción del sentido del lugar: Una aproximación por medio de textos narrativos y fotografías. Innov. Educ. 2016, 16, 83-110.

29. UE. Comité Europeo de las Regiones. Hacia un enfoque integrado del Patrimonio Cultural Europeo. 2015. Available online: https:/ / eur-lex.europa.eu/legal-content/ES/TXT/?uri=CELEX\%3A52014IR5515 (accessed on 3 April 2020 ).

30. Cortés, J. Identidad territorial y paisaje. Evolución morfológica de los núcleos de Castilla y León. Observatorio Medioambient. 2015, 18, 131-147. [CrossRef]

31. Hernández, M. El paisaje como seña de identidad territorial. Bolet. Asoc. Geógr. Españ. 2009, 49, 69-183.

32. UNESCO. Convención para la Salvaguardia del Patrimonio Cultural Inmaterial. Available online: https://ich.unesco.org/es/ convenci\%C3\%B3n\#art2 (accessed on 23 April 2021).

33. BOE n. 126, de 27-05-2015. Ley 10/2015, de 26 de mayo, para la Salvaguardia del Patrimonio Cultural Inmaterial. Available online: https: / /www.boe.es/eli/es/1/2015/05/26/10/con (accessed on 24 April 2021).

34. MEA (Millennium Ecosystem Assessment). Ecosystems and Human Well-being: Synthesis; Island Press: Washington, DC, USA, 2005.

35. Cañizares, M.C.; Ruiz, A.R. Paisajes del viñedo y servicios ecosistémicos culturales. Aportación metodológica desde el análisis territorial integrado. In Desafíos y Oportunidades de un Mundo en Transición. Una Interpretación Desde la Geografía; Farinós, J., Ed.; Tirant Humanidades y Universitat de València: Valencia, Spain, 2020; pp. 417-428.

36. Del Barrio, M.J.; Devesa, M.; Herrero, L.C. Evaluating intangible cultural heritage: The case of cultural festivals. City Cult. Soc. 2012, 3, 235-244. [CrossRef]

37. UE. Decisión (UE) 2017/864 del Parlamento Europeo y del Consejo de 17 de Mayo de 2017 Sobre un Año Europeo del Patrimonio Cultural, 2018. Available online: https:/ / eur-lex.europa.eu/legal-content/EN/TXT/?uri=CELEX\%3A32017D0864 (accessed on 20 January 2022).

38. Pillet, F. Espacio y Ciencia del Territorio. Proceso y Relación Global-Local; Biblioteca Nueva: Madrid, Spain, 2008.

39. Ruiz, A.R.; Cañizares, M.C. Paisaje cultural del viñedo e identidad territorial en Castilla-La Mancha. In Naturaleza, Territorio y Ciudad en un Mundo Global; Universidad Autónoma de Madrid y Asociación de Geógrafos Españoles: Madrid, España, 2017; pp. 2.225-2.234.

40. Elías, L.V. Atlas del Cultivo Tradicional del Viñedo y de Sus Paisajes Singulars; Ministerio de Agricultura, Pesca y Alimentación: Madrid, España, 2016.

41. Martínez, M.; Molinero, F.; Baraja, E. Criterios de la UNESCO para la declaración de regiones vitícolas como paisaje cultural: Su aplicación al caso español. Bolet. Asoc. Españ. Geogr. 2019, 80, 1-33. [CrossRef]

42. Castillo, J. Carta de Baeza sobre el Patrimonio Agrario. Sevilla. Universidad Internacional de Andalucía: Sevilla (España), 2013. Available online: http:/ / www.unia.es/explorar-catalogo/item/carta-de-baeza-sobre-patrimonio-agrario (accessed on 20 January 2022).

43. UNESCO. Available online: https://es.unesco.org/themes/patrimonio-cultural-inmaterial (accessed on 23 October 2021).

44. Lenzerini, F. Intangible Cultural Heritage: The Living Culture of Peoples. Eur. J. Int. Law 2011, 22, 101-120. [CrossRef]

45. Winkler, A.J.; Nicholas, K.A. More than wine: Cultural ecosystem services in vineyard landscapes in England and California. Ecol. Econ. 2016, 124, 86-98. [CrossRef]

46. Ruiz Pulpón, A.R.; Cañizares, M.C. Potential of vineyard landscapes for sustainable tourism. Geosciences 2019, 9, 472. [CrossRef]

47. Tenberg, A.; Fredholme, S.; Eliasson, I.; Knez, I.; Saltzman, S.; Wetterberg, O. Cultural ecosystem services provided by landscapes: Assessment of heritage values and identity. Ecosyst. Serv. 2012, 2, 14-26. [CrossRef]

48. Fish, R.; Church, A.; Winter, M. Conceptualising cultural ecosystem services: A novel framework for research and critical engagement. Ecosyst. Serv. 2016, 21, 208-217. [CrossRef]

49. UNESCO. Available online: https:/ / ich.unesco.org/es/usos-sociales-rituales-y-00055 (accessed on 11 November 2021).

50. UNESCO. Available online: https://ich.unesco.org/es/listas (accessed on 11 November 2021).

51. Turismo de Castilla-La Mancha. Available online: http://www.turismocastillalamancha.es/fiestas/fiestas-del-vino-devaldepenas-3276 (accessed on 11 November 2021).

52. Cañizares, M.C.; Ruiz Pulpón, Á.R. Bases para la declaración como Bien de Interés Cultural del Paisaje del vino y el viñedo de la DO Valdepeñas (Castilla-La Mancha). In Treinta Años de Política Agraria Común en España: Agricultura y Multifuncionalidad en el Contexto de la Nueva Ruralidad; Ruiz Pulpón, A.R., Serrano de la Cruz Santos-Olmo, M.A., Plaza Tabasco, J., Eds.; Almud. Ediciones de Castilla-La Mancha: Ciudad Real, Spain, 2016; pp. 551-566.

53. Pedraja, M.; Marzo, M. El desarrollo del enoturismo desde la perspectiva de la bodega familiar. Cuadernos Turismo 2014, 34, 233-418.

54. Rodríguez, J.; López-Guzmán, T.; Cañizares, S.M.; Jiménez, M. Turismo del vino en el Marco de Jerez, Un análisis desde la perspectiva de la oferta. Cuadernos Turismo 2010, 26, 217-234.

55. Dordio, V. Los vinos de Murdia. Contribución de José Sarasa. Cuadernos Turismo 2011, 27, 305-320.

56. Pillet, F. El turismo de interior y el patrimonio territorial en Castilla-La Mancha. Cuadernos Turismo 2011, 27, 725-741.

57. Baraja, E.; Herrero, D.; Martínez, M.; Plaza, J.I. Turismo y desarrollo vitivinícola en espacios de montaña con “alta densidad patrimonial". Cuadernos Turismo 2019, 43, 97-122. [CrossRef]

58. Ruta del Vino de La Mancha. Available online: https: / /www.rutadelvinodelamancha.com (accessed on 21 September 2021).

59. Ruta del Vino de Valdepeñas. Available online: https:/ / wineroutesofspain.com/rv-de-valdepenas (accessed on 21 September 2021). 
60. Dos Santos Queirós, A. Material and immaterial heritage: From the concept of cultural landscape to the tourist product. J. Tour. Herit. Res. 2019, 2, 90-119.

61. Arroyo, F. La toponimia como Patrimonio Cultural Inmaterial. Bolet. Real Soc. Geogr. 2018, CLIII, 33-60.

62. DO C 183 de 14.6.2014. Conclusiones del Consejo de 21 de Mayo de 2014 Sobre el Patrimonio Cultural Como Recurso Estratégico para una Europa Sostenible. Available online: https:/ / eur-lex.europa.eu/legal-content/ES/TXT/PDF/?uri=CELEX:52014XG061 $4 \&$ from $=$ BG (accessed on 12 November 2021).

63. Vecco, M. A definition of cultural heritage: From the tangible to the intangible. J. Tour. Herit. Res. 2010, 11, 321-324. [CrossRef]

64. Velasco, H.M. Las amenazas y riesgos del patrimonio mundial y del patrimonio cultural inmaterial. Anale Museo Nacl. Antropol. 2012, XIV, 10-19.

65. Elías, L.V. Fiestas del Vino en España y Portugal. RIVAR 2021, 8, 264-286. [CrossRef]

66. Lacoste, P.; Aruj, A. Antropología, cultura y enoturismo en la Fiesta Nacional de la Vendimia (Mendoza, Argentina). In Enoturismo Sostenible e Innovador. Modelos de Éxito Alrededor del Mundo; Compés, R., Szolnoki, G., Eds.; Cajamar Rural: Alicante, Spain, 2020; pp. 83-94.

67. Riggio, C.A. La Fiesta Nacional de la Vendimia (Mendoza, Argentina): Patrimonio inmaterial. Estud. Soc. Contemp. 2020, 1, 121-136.

68. Villaseñor, I.; Zolla, E. Del patrimonio cultural inmaterial o la patrimonialización de la cultura. Cult. Represent. Soc. 2012, 6, 75-101.

69. UE. Año Europeo del Patrimonio Cultural 2018. Available online: https://europa.eu/cultural-heritage/about_es.html (accessed on 2 April 2020). 